\title{
A FENNTARTHATÓ FOGYASZTÁS IRÁNT ELKÖTELEZETT FOGYASZTÓI CSOPORT, A LOHAS SZEGMENS JELLEMZÓI
}

\author{
- nolo \\ THE CHARACTERISTICS OF THE LOHAS SEGMENT, THE CONSUMER GROUP \\ WHICH IS DEVOTED TO SUSTAINABLE CONSUMPTION

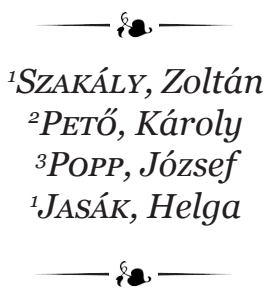 \\ ${ }^{1}$ Debreceni Egyetem, Gazdaságtudományi Kar, Marketing és Kereskedelem Intézet \\ (University of Debrecen, Faculty of Economics, Institute of Marketing and Commerce) \\ ²Debreceni Egyetem, Gazdaságtudományi Kar, Vidékfejlesztés, Turizmus- és Sportmenedzsment Intézet \\ (University of Debrecen, Faculty of Economics, Institute of Rural Development, Tourism and Sport Management) \\ 32Debreceni Egyetem, Gazdaságtudományi Kar, Ágazati Gazdaságtan és Módszertani Intézet \\ (University of Debrecen, Faculty of Economics, Institute of Sector Economics and Methodology) \\ H-4032 Debrecen, Böszörményi út 138. \\ e-mail: szakaly.zoltan@econ.unideb.hu
}

[a]

Sustainable consumption is a megatrend influencing consumer habits today. Our research was carried out to find out information - with the help of international and national literature - about the general and differentiating characteristics and the size of the consumer group devoted to sustainable consumption. Our aim was also to sum up the economic importance of the segment. This "new type" of consumer-buyer group is called LOHAS (Lifestyle of Health and Sustainability) by professionals. An important feature of the segment is that they consider all the three pillars of sustainable development (economic, social and ecological) in their shopping decisions. LOHAS consumers live their life health-consciously. Their devotion to sustainability is reflected in purchasing environmental-friendly, socially responsible products. Besides this, it can also be claimed about them that they are early adopters and they are able to influence the opinion of their friends and family. They are less price-sensitive, and they are characteristically brand-loyal. These characteristics make them the attractive target of a lot of marketing activities. It is hard to describe the LOHAS lifestyle only with demographic features since their devotion to sustainable consumption is determined by mostly personal values and the individual's value order. LOHAS lifestyle has five, well defined value categories that direct the individuals' behavior. They are authentic values, health-conscious values, ethic values, individualist values and environmental-conscious values. The LOHAS group is also characterized by such a hybrid lifestyle in which different characteristics merge with each other. The LOHAS "phenomenon" is mostly characteristic of the western world, but it is becoming widespread in the Asian region's consumer society. In the developed countries the size of the group may reach $25 \%$. For today the approach and value order characterizing the LOHAS consumer's lifestyle have appeared within the Hungarian population as well. Hungarian researchers estimate the size of this group different - between 4 and $30 \%$ - depending on the values expected during segmentation. The LOHAS trend influences all the branches of economy calling companies for innovation that meets the needs of the consumers who prefer hybrid lifestyle, and for environmental and social responsibility. However, the strongest influence appears in the food industry. It is worth mentioning that some members of the tertiary sector have also realized the opportunities lying behind them. Besides the economic importance of the LOHAS consumer group, it is important to mention that their inner values and views envisage a healthier society and a cleaner and more livable environment. 


\section{BEVEZETÉS - INTRODUCTION}

$\mathrm{Az}$ 1990-es évekig a marketing fókuszában azok a cserefolyamatok álltak, amelyekben a hatalom birtokosa a termelő volt [1]. Az erőforrások korlátozottságának és a környezeti kihívásoknak (pl. éghajlatváltozás, ózonréteg elvékonyodása, talajpusztulás, elsivatagosodás, levegő- és vízszenynyezés, ivóvízhiány) a felismerésével, a harmadik évezred elején azonban olyan globális kérdések foglalkoztatják a marketing szakembereket, mint a fenntartható fejlődés és a fenntartható fogyasztás [2; 3; 4; 5]. A fenntarthatóság előtérbe kerüléséhez nagymértékben hozzájárult az előbbiekben említett tényezók mellett az egyének egészségtelen életmódjából fakadó civilizációs betegségek rohamos terjedése [6], amelyek a WHO (2012) adatai szerint a halálozások 63\%-áért felelősek [7]. Az 1992-ben Rio de Janeiro-ban megrendezett ENSZ Környezet és Fejlődés Konferencián (UNCED) újragondolták a fenntarthatóság kérdését: a fogyasztás szempontjából közelítették meg, és bevezették a fenntartható fogyasztás fogalmát $[8 ; 9 ; 10 ; 11]$, amely napjaink egyik, a fogyasztói szokásokat befolyásoló megatrendje a fejlett országokban [12; 13]. Mindez alátámasztja a fenntartható fogyasztás iránt elkötelezett fogyasztói csoportok vizsgálatának aktualitását és szükségszerűségét [14]. Munkánk során azt tüztük ki célul, hogy a nemzetközi és a hazai szakirodalom segítségével feltérképezzük a szegmens általános és differenciáló jellemzőit, valamint a méretét. Célkitüzésként fogalmaztuk meg továbbá, hogy összefoglaljuk a csoport gazdasági jelentőségét.

\section{A LOHAS FOGYASZTóK JELLEMzói \\ - Characteristics OF THE LOHAS CONSUMERS}

A fenntartható fogyasztás akkor valósulhat meg, ha az egyén erősen elhivatott, illetve következetes az általa választott értékrend validálásában, és ennek megfelelően alakulnak a fogyasztási motivációi, melyek érvényre jutnak a konkrét vásárlási szituációkban is. Tehát ezt az „új típusú” fogyasztói-vásárlói magatartásformát tekinthetjük a „fenntartható fogyasztásnak”, és az iránta leginkább elkötelezett fogyasztókat nevezi a szakirodalom LOHAS-nak (Lifestyle of Health and Sustainability) [15; 16; 17]. Ray és Anderson (2000), Everage (2002), valamint Aue (2008) „kulturális kreatívokként” (Cultural Creatives) említi őket, utalva a jelenség kultúraváltozást előidéző hatására $[18 ; 19 ; 20]$. Fontos ismérve a csoportnak, hogy vásárlási döntéseiknél a fenntartható fejlődés mindhárom pillérét (gazdasági, társadalmi és ökológiai) figyelembe veszik $[15 ; 16 ; 17]$.

A Natural Marketing Institute (NMI) 2002-ben egy új szegmentációs modell segítségével, kvantitatív fogyasztói felmérés keretében szegmentálta a környezetbarát termékek piacát a fogyasztók környezet, etikus fogyasztás és fenntarthatóság iránti attitűdjei alapján, illetve, hogy ezek az attitüdök milyen hatást gyakorolnak a vásárlói magatartásra. A kutatás eredményei alapján a LOHAS fogyasztói csoport attitúdjeit leginkább a környezet, a társadalom és a társadalmilag felelős üzletvitel határozza meg. Korai elfogadók, képesek befolyásolni családjuk és barátaik véleményét, kevésbé árérzékenyek és jellemzően márkahűek. Összességében megállapítható, hogy társadalmi szerepük és belső értékeik alkotják azt a bázist, mely számos marketingaktivitás vonzó célpontjává teszi őket [21;22].

A LOHAS fogyasztók demográfiai szerkezete a Natural Marketing Institute (NMI) kutatásai alapján az alábbiak szerint írható le: a tipikus LOHAS fogyasztó középkorú nő, családi állapotát tekintve házas és többségük gyermektelen, de nem hanyagolható el a szegmensen belül azok aránya sem, akiknek 6-17 év közötti gyermekük van. A LOHAS fogyasztók általában magas jövedelemmel és felsőfokú végzettséggel rendelkeznek [21]. Ray (1996) az általa „kulturális kreatívoknak” nevezett csoportot a következőképpen jellemezte: rendszerint a felső- és középső társadalmi rétegekből kerülnek ki és 50\%-kal több nő mondható az irányzat iránt elkötelezettnek, mint férfi [16]. Megjegyzendő továbbá, hogy megjelent napjainkban a fiatal LOHAS-osok csoportja is. Ők a millenniumi generáció azon tagjai, akik kiemelten fontosnak tartják a környezetvédelmi szempontokat. A szerényebb anyagi helyzetük ellenére is hajlandóak többet fizetni a környezetbarát termékekért. Esetükben mindez az önkifejezés egyik formájaként értelmezhető. A „zöld” fogyasztás iránti elkötelezettségük fóként nyitottságuknak és egyetemi, főiskolai tanulmányaiknak, illetve az ott szerzett tapasztalatoknak köszönhető [23; 24].

\section{A LOHAS fOgYasztók ÉRTÉKRENDJE - VALUES OF THE LOHAS CONSUMERS}

Kizárólag demográfiai jellemzőkkel (pl. nem, életkor, iskolai végzettség, jövedelem) nehezen írható körül a LOHAS életstílus, ugyanis - mint már utal- 
tunk rá - elsősorban a személyes értékek, az egyén értékrendje határozza meg a fenntartható fogyasztás iránti elkötelezettséget, vagyis az értékrend a LOHAS életstílus megértésének kulcsfontosságú tényezője [25].

Miután az értékek megválasztása, az értékorientáció a különféle döntések irányítója, és emellett viszonylag stabil jellemzője egy-egy embernek, fogyasztói csoportnak, így vizsgálata kiemelt jelentőségű a fogyasztói magatartás-kutatásokban $[1 ; 26]$. Az értékorientáció korszakai jól körülhatárolhatók [27]. Az anyagi javak fontosságának értékorientációjából jutottunk el az 1970-es években a hedonizmushoz, mely az alábbi kulcsszavakkal jellemezhető: élmény, teljesítmény, én, anyagiasság, szerelem, móka. Napjainkban egy újabb értékváltásnak lehetünk tanúi, mégpedig a humán értékek felértékelődésének. Az értékorientáció ezen korszakának jellemzője a túlzott fogyasztástól való elfordulás, a környezetre való figyelés, a saját egészség lehetőség szerinti óvása, valamint a természetesség és az autentikusság keresése $[1 ; 28$; 29]. A leírtak lényegében a LOHAS csoport jellemvonásait tükrözik. Az értékrend tehát kiemelkedő jelentőséggel bír egyrészt a LOHAS szegmens fogyasztói magatartásának vizsgálata, másrészt a lakosságon belüli arányuk becslése során.

Az elmúlt évtizedekben az értékek és az életstílus közötti kapcsolatot - különböző aspektusokból - több kutatás is vizsgálta. Ezek közül kiemelhető az emberi értékek és az élelmiszer-fogyasztó életstílusa közötti kapcsolatok feltárása $[6 ; 30 ; 31$; 32]. Az értékek hatását az egészségmagatartásra - melyet az életstílus nagymértékben befolyásol ugyancsak többen elemezték. Grube et al. (1984) az értékrendszer és a dohányzás [33], Toler (1975) pedig a személyes értékek és az alkoholizmus közötti kapcsolatot vizsgálta [34].

A LOHAS fogyasztók - mint ahogy a mozaikszó tartalma is mutatja - életüket az egészségtudatosság jegyében élik [35], mindezt oly módon teszik, hogy közben másokért is felelősséget éreznek. A fenntarthatóság iránti elkötelezettségük a környezetbarát, társadalmilag felelős termékek vásárlásában nyilvánul meg. A Natural Marketing Institute felmérése szerint legalább kétszer annyi LOHAS fogyasztó vásárol a környezetbarát csomagolással ellátott élelmiszerekből, mint az egyéb fogyasztói szegmensekben [36]. A környezetvédelmi szempontok mellett a LOHAS fogyasztók vásárlási döntéseiben a társadalmi felelősségvállalás értékei is tükröződnek [21;37], mely többek között a tisztességes kereskedelem, az erkölcsös magatartás és a társadalmi igazságosság demonstrálásában nyilvánul meg. Ezenfelül az individuális értékek - a wellness, az élvezet, a kényelem és a személyes fejlődés - keresése is jellemző a csoportra [19; 35]. Az etikus és az individuális értékek Ramirez (2013) szerint is meghatározó jelentőségűek a fenntartható fogyasztás szempontjából [25]. Emellett számos olyan tényező is említhető, amit a LOHAS következetesen elutasít: materializmus (anyagiasság), kapzsiság, kirívó társadalmi egyenlőtlenségek, a társadalom idősekkel, nőkkel és gyermekekkel szembeni érdektelensége és a cinizmus. Szinte minden nagy szervezetet kritikával illetnek a modern társadalomban [18].

Összességében elmondható, hogy a LOHAS életstílus öt, jól körülhatárolható értékkategória köré szerveződik, amelyek az egyének magatartását irányítják $[18 ; 20]$ : autentikus értékek, egészségtudatos értékek, etikus értékek, individualista értékek és környezettudatos értékek [14].

A németországi Zukunftsinstitute kutatásai a csoport további fontos sajátosságára hívták fel a figyelmet, miszerint a LOHAS csoport tagjaira olyan hibrid életstílus jellemző, amelyben különböző karakterisztikák egyesülnek egymással (pl. egészség és élménykeresés, individualizmus, de nem egocentrikusság). Döntéseikben kiemelt szerep jut a környezeti és egészségi szempontoknak, ennek ellenére nem mondanak le a hedonizmusról és az élménykeresésról sem. A szegmens értékrendszere tökéletesen egyesíti a látszólag egymásnak teljesen ellentmondó tényezőket $[1 ; 17 ; 20 ; 38]$. Ramirez (2013) is utal az effajta kettősségre, ambivalenciára a kényelem és a fenntartható fogyasztás vonatkozásában [25].

\section{A LOHAS SZEgmenS MÉRETE - SIZE OF THE LOHAS SEGMENT}

A LOHAS piac globális méretét 500 milliárd dollárra becsülik [39]. A ,jelenség” kiváltképp a nyugati világra jellemző, de egyre inkább áthatja az ázsiai régió fogyasztói társadalmát is [20]. A fejlett országokban akár a 25\%-ot is elérheti azon fogyasztók aránya, akik vásárlási döntéseiket etikai és környezetvédelmi szempontok figyelembevételével hozzák meg [39].

A csoport abszolút nagyságát Schulz (2008) az Amerikai Egyesült Államokban, mintegy 40 millióra becsüli, amely a teljes amerikai lakosság 1319\%-át reprezentálja [17]. Ezzel ellentétben Cohen (2007) és Ramirez (2013) szerint hozzávetőlegesen a felnőtt lakosság 30\%-a, vagyis 60 millió fogyasztó alkotja a szegmenst az USA-ban [5; 25]. 1\%-os éves piacbővüléssel számolnak a szakemberek, amely a több mint 300 milliárd dolláros amerikai piacot 
[25] akár 10\%-kal is növelheti évente [40]. Schulz (2008) szerint Európában a LOHAS fogyasztók létszáma meghaladja a 49 millió főt, amely a lakosság 18\%-át testesíti meg. Németországban az európai átlaghoz hasonló arány (17\%) érvényesül [17].

A LOHAS Japánban is gyorsan terjed. A japán E-Square Inc. 2005-ben végzett felmérése szerint a felnőtt japán lakosság 29\%-ára jellemző a LOHAS életstílus [41]. Új-Zélandon a fogyasztók egyharmada sorolható ebbe a kategóriába [39]. Ausztráliában pedig 4 millió embert, a felnőtt lakosság megközelítőleg egynegyedét foglalja magában a LOHAS piac, melynek éves kiadása 12 milliárd ausztrál dollár [39; 42]. 2005 óta Kínában is széles körben terjed a ,jelenség”, amely az egészség (egészséges élet), az érzelmi jólét és a fenntarthatóság koncepciójának tekintetében illeszkedik a kínai kultúra filozófiájához [43].

A LOHAS szegmens méretét prognosztizáló eredmények tág intervallumban szóródnak, ami a kutatások eltérő módszertanával és a különböző szegmentációs modellekkel magyarázható. A fogyasztói csoport nagysága mellett a LOHAS tipológiák is meglehetősen heterogének nemzeti összehasonlításban, azaz az egyes országokban a szegmensek eltérő magatartásjellemzőket mutatnak. Az eltérések helyi, kulturális, környezeti és társadalmi sajátosságokra vezethetők vissza [42].

$\mathrm{Az}$ értékorientáció korszakváltása a nyugati országokban ugyan előbb következett be, mint a kelet-közép európai országokban, de mára a LOHAS fogyasztó életstílusát jellemző szemléletmód, értékrend a magyar lakosságon belül is megjelent, melyet több hazai felmérés eredménye is igazol [44]. A hazai kutatók eltérő nagyságúra - 4-30\% közötti intervallum - becsülik e csoport lakosságon belüli arányát, attól függően, hogy mely értékek teljesülésével számolnak a szegmentáció során. Törőcsik (2007) szerint a szegmens mérete nem éri el a 25-30\%-ot, azonban növekvő tendenciát feltételez [1]. Lehota, Horváth és Rácz (2013) kutatásának eredményei alapján a hibrid életstílust preferáló LOHAS fogyasztók Magyarországon megközelítőleg a lakosság 8\%-át reprezentálják. A legelkötelezettebbek aránya pedig 4\% [44]. Végezetül Rácz (2013) 20\%-ra becsüli a csoport méretét a 15 év feletti magyar népességen belül, élelmiszerekre fordított kiadásaik pedig megközelítik a 300 milliárd Ft-ot [14].

\section{A LOHAS SZEGMENS GAZDASÁGI JELENTóSÉGE - THE ECONOMIC IMPORTANCE OF THE LOHAS SEGMENT}

A LOHAS trend valamennyi gazdasági ágazatban érezteti hatását, a hibrid életstílust preferáló fogyasztók igényeihez igazodó innovációra, környezeti- és társadalmi felelősségvállalásra ösztönözve a vállalatokat $[19 ; 35 ; 45]$.

A LOHAS fogyasztói csoport elkötelezett a fenntarthatóság elve iránt, ami meghatározza alapértékeiket [15] és megnyilvánul az életstílusukban. Ebből az következik, hogy életük minden területét áthatja az egészség és a fenntarthatóság szemlélete. Ennek ismeretében nem meglepő, hogy a LOHAS számos ágazatban érezteti a hatását, melyek az alábbiak: élelmiszer, divat, egészség, design, turizmus, szabadidő és média [38]. Igény mutatkozik továbbá az energiatakarékos berendezések és a napelemek iránt is [2]. A legerősebb hatás azonban az élelmiszeriparban jelentkezik. A Nielsen és a Natural Marketing Institute felmérése szerint a LOHAS fogyasztók az „átlagos” fogyasztókhoz képest többet költenek az előrecsomagolt élelmiszerekre. A vizsgált fogyasztói szegmens körében az alábbi termékkategóriákban kiugróan magas értékbeli vásárlás figyelhető meg: friss termékek, gabonafélék, levesek, szájhigiéniai termékek, konzerv zöldségek, vaj és margarin, konyhakész ételek, tojás, gyógyszerek, háztartási kellékek, háztartási tisztítószerek, szezonális füszerek, kivonatok, olajok, lekvárok, zselék, tésztafélék, diófélék, villanykörték, vitaminok, palackozott vizek [46]. Az általuk hordozott értékeknek és a funkcionális előnyöknek köszönhetően nagy népszerüségnek örvendenek a különböző funkcionális élelmiszerek is, úgymint az egészségvédő- és bioélelmiszerek [47].

A LOHAS jelenség nemcsak az élelmiszerágazat számára jelent új perspektívát. A tercier szektor egyes szereplői is felfigyeltek a bennük rejlő lehetőségekre, és törekednek arra, hogy szolgáltatásaikat az igényeiknek megfelelően differenciálják. Az igazán elkötelezett LOHAS-osok esetében az étteremválasztás során is érvényesülnek a fenntarthatósági, egészségmegőrzési és környezetvédelmi szempontok [48]. Mi több Amerikában öko-bankokkal is találkozhatunk, amelyek többek között ún. zöld jelzáloghiteleket és autóhiteleket kínálnak [39]. A LOHAS értékek és a falusi turiz- 
must életre hívó ellentrendek - úgymint személyre szabott élmények versus „tömegszolgáltatás”, a lokalitás preferálása a globalitással szemben, lassítás a gyorsuló élet ellenében, a természetes előnyben részesítése a mesterségessel szemben - összhangját alapul véve megítélésünk szerint Todt és Kastenholz (2010) joggal nevezi a falusi turizmust „új turizmusnak” vagy „LOHAS piacnak” [49; 50]. A szegmens jelen van továbbá a kozmetikai termékek piacán is. Franciaországban és Németországban a legnagyobb ennek a termékkategóriának a fogyasztói bázisa. Végül, de nem utolsósorban nem hagyható figyelmen kívül az a tény sem, hogy a LOHAS fogyasztók hajlandók többet fizetni azokért a termékekért, amelyek hordozzák az általuk képviselt értékeket [39; 51].

A leírtak alapján a LOHAS jelentősége megkérdőjelezhetetlen, ami létjogosultságot ad bizonyos nem-érzékszervi tényezőknek a termelési és gyártási folyamatokban, ezek ugyanis fontos szerepet kapnak akkor, amikor a LOHAS fogyasztók terméket vagy szolgáltatást választanak. Ilyen többek között az adalékanyag- és tartósítószer-mentesség, a táplálkozási érték, az állatjóléti kérdések, az egészségjavító hatás, az ökológiai rendszerek védelme és a természeti erőforrások kizsákmányolásának mérséklése, illetve, hogy mindezek társadalmilag igazságos módon valósuljanak meg [19; 52; 53].

Összefoglalásként megállapítható, hogy a LOHAS fogyasztók sajátos értékítélete számos területen új helyzetet eredményez, ami az ágazati szereplőket és a marketingszakembereket egyaránt kihívás elé állítja. A szegmens valódi jelentősége azonban nem ebben rejlik, ugyanis nem hunyhatunk szemet a bevezetésben nevesített környezeti és társadalmi problémák felett. Így a LOHAS fogyasztói csoport gazdasági jelentősége mellett nem szabad megfeledkezni arról sem, hogy belső értékeik és szemléletmódjuk egy egészségesebb társadalmat és egy tisztább, élhetóbb környezet helyeznek kilátásba. Ezek alapján úgy gondoljuk, hogy méltán kelthet érdeklődést az, hogy mekkora az arányuk a magyar társadalomban, illetve mi jellemzi vásárlási döntéseiket.

\section{IRODALOMJEGYZÉK - REFERENCES}

[1] Töröcsik M.: A tudatos fogyasztást és az egészséget preferáló új fogyasztói trendcsoport a LOHAS csoport megjelenése Magyarországon. In: Élelmiszer, táplálkozás és marketing. 2007. 4 (1) 41-45.

[2] Kotler, P.: Reinventing Marketing to Manage the Environmental Imperative. In: Journal of Marketing. 2011. 75 (4) 132-135.

[3] Achrol, R. - Kotler, P.: Frontiers of the Marketing Paradigm in the Third Millennium. In: Journal of the Academy of Marketing Science. 2012. 40 (1) 35-52.

[4] Scott, W. G.: An Introduction to Sustainable Marketing. In: Etica Pubblica, Finanza, Globalizzazione (Ed.: Benigni, C. - Carletto, S. - D’Orazio, E. - Sacconi, L. - Scott, W. G. Unnia, M.). Medusa, Milan, 2005, 25-42.

[5] Cohen, M. J.: Consumer Credit, Household Financial Management, and Sustainable Consumption. In: International Journal of Consumer Studies. 2007. 31 (1) 57-65.

[6] Szakály Z.: Táplálkozásmarketing. Mezőgazda Kiadó, Budapest, 2011.

[7] World Health Organization (WHO): World Health Statistics 2012. WHO Press, Geneva, 2012.

[8] Hofmeister Tóth Á. - Kelemen K. - Piskóti M.: A fenntartható fogyasztás jellemzői és trendjei Magyarországon és a régióban. In: Fenntartható fogyasztás? A fenntartható fogyasztás gazdasági kérdései (Szerk.: Csutora M. - Hofmeister Tóth Á.). AULA Kiadó, Budapest, 2011, 53-76.

[9] International Organisation of Consumers Unions (IOCU): Beyond the Year 2000: the Transition to Sustainable Consumption: a Policy Document on Environmental Issues. IOCU ROENA, The Hague, 1993.

[10] Organization for Economic Cooperation and Development (OECD): Sustainable Consumption and Production: Clarifying the Concepts. OECD, Paris, 1997. 
[11] Organization for Economic Cooperation and Development (OECD): Towards Sustainable Consumption Patterns: a Progress Report on Member Country Initiatives. OECD, Paris, 1998.

[12] Törőcsik M.: Fogyasztói magatartás - Insight, trendek, vásárlók. Akadémiai Publishing, Budapest, 2011.

[13]Z_punkt GmbH: Megatrends. Z_punkt $\mathrm{GmbH}$, The Foresight Company, Köln, Karlsruhe, Berlin, 2008.

[14] Rácz G.: Az értékek változásának és a fenntartható fejlődés trendjének hatása a hazai élelmiszerfogyasztásra (Doktori értekezés). Szent István Egyetem, Gazdaságés Társadalomtudományi Kar, Gazdálkodás és Szervezéstudományok Doktori Iskola, Gödöllő, 2013.

[15] Kreeb, M. - Motzer, M. - Schulz, W. F.: LOHAS als Trendsetter für das Nachhaltigkeitsmarketing. In: Medialisierung der Nachhaltigkeit. Das Forschungsprojekt balance(f): Emotionen und Ecotainment in den Massenmedien (Ed.: Schwender, C. Schulz, W. - Kreeb, M.). Metropolis, Marburg, 2008, 303-314.

[16] Ray, P.: The Rise of Integral Culture. In: Noetic Sciences Review. 1996. 4-15.

[17] Schulz, W. F.: Der Markt für nachhaltige Produkte, Eine Chance für den Mittelstand, Vortrag im Rahmen der BMZ/DIHK Auftakveranstaltung „Mittelstand schaft Werte”. Berlin, 6. Dec. 2008.

[18] Ray, P. H. - Anderson, S. R.: The Cultural Creatives: How 50 Million People Are Changing the World. Harmony Books, New York, 2000.

[19] Everage, L.: Understanding the LOHAS Lifestyle. In: Gourmet Retailer. 2002. 23 (10) 85.

[20]Aue, S.: Lifestyle of Health and Sustainability (LOHAS): Eine neue Form politischer Partizipation. Druck und Bindung, Norderstedt, 2008.

[21] Natural Marketing Institute (NMI): Understanding the LOHAS MarketTM Report. Natural Marketing Institute, Harleysville, 2008.

[22]French, S. - Rogers, G.: Understanding the LOHAS Consumer: The Rise of Ethical Consumerism. In: LOHAS Journal [Online]. 2006. URL: http://www.lohas.com/LohasConsumer (Letöltés dátuma: 2014. május 16.)
[23]Royne, M. B. - Martinez, J. - Oakley, J. - Fox, A. K.: The Effectiveness of Benefit Type and Price Endings in Green Advertising. In: Journal of Advertising. 2012. 41 (4) 85-102.

[24] Gurău, C.: A Life-Stage Analysis of Consumer Loyalty Profile: Comparing Generation X and Millennial Consumers. In: Journal of Consumer Marketing. 2012. 29 (2) 103-113.

[25]Ramirez, E.: The Consumer Adoption of Sustainability-Oriented Offerings: Toward a Middle-Range Theory. In: Journal of Marketing Theory \& Practice. 2013. 21 (4) 415428.

[26]Grunert, S. C. - Juhl, H. J.: Values, Environmental Attitudes, and Buying of Organic Foods. In: Journal of Economic Psychology. 1995. 16 39-62.

[27]Smith, W. J. - Clurman, A. S.: Rocking the Ages: The Yankelovich Report on Generational Marketing. HarperBusiness, New York, 1997.

[28]Horváth Á. - Fürediné Kovács A. - Fodor M.: Az értékrend hatása a táplálkozásra. In: Élelmiszer, táplálkozás és marketing. 2005. 2 (1-2) 69-76.

[29]Martin, D. - Schouten, J.: Sustainable Marketing. Pearson Education Inc., New Jersey, 2011.

[30]Lusk, J. L. - Briggeman, B. C.: Food values. In: American Journal of Agricultural Economics. 2009. 91 (1) 184-196.

[31] Brunso, K. - Grunert, K. G. - Bredahl, L.: An Analysis of National and Cross-national Consumer Segments Using the Food-related Lifestyle Instrument in Denmark, France, Germany and Great Britain. In: MAPP Working paper. 1996. (35) 1-58.

[32]Grunert, K. G. - Brunso, K. - Bisp, S.: Food-related life style: Development of a cross-culturally valid instrument for market. In: MAPP Working paper. 1993. (12) 1-44.

[33]Grube, J. W. - Weir, I. L. - Getzlaf, S. - Rokeach, M.: Own Values System, Value Images, and Cigarette Smoking. In: Personality and Social Psychology Bulletin. 1984. 10 306313.

[34]Toler, C.: The Personal Values of Alcoholics and Addicts. In: Journal of Clinical Psychology. 1975. 31 (3) 554-557.

[35]Schüpbach,S.S. - Gröli, M. - Dauwalder, P. - Amhof, R.: LOHAS Lifestyle of Health and Sustainability. Ernst\&Young, Switzerland, 2008. 
[36]Spaulding, M.: Market Trends. In: Converting Magazine. 2006. 24 (12) 4.

[37] Bamossy, G. - Englis, B.: Talk the Green Talk, Shop the Green Walk? In: Advances in Consumer Research. 2010. 37 32-35.

[38]Wenzel, E. - Kirig, A. - Rauch, C.: Zielgruppe LOHAS - Wie der grüne Lifestyle die Märkte erobert. Zukunftinstitut, Kelkheim, 2007.

[39]Paterson, K.: A New Level of Consciousness. In: NZ Business. 2008. 22 (2) 28-29.

[40]Peterson, E.: Who's Changing Whom? In: LOHAS Journal [Online]. 2006. URL: http:// www.lohas.com/whos-changing (Letöltés dátuma: 2014. február 7.)

[41] Ekberg, P.: The Keywords Is LOHAS. In: Economy, Culture \& History Japan Spotlight Bimonthly. 2006. 25 (2) 24-25.

[42]Baker, A.: The Growth of LOHAS Internationally. In: LOHAS Journal. Spring 2008. URL: http://www.lohas.com/sites/ default/files/lohasintrntlgrowth_sm.pdf (Letöltés dátuma: 2014. május 16.)

[43]Kan, J.: An Environmentally Friendly China? In: Global Cosmetic Industry. 2010. 178 (4) 40-45.

[44]Lehota J. - Horváth Á. - Rácz G.: A potenciális LOHAS fogyasztók megjelenése Magyarországon. In: Marketing \& Menedzsment. 2013. 47 (4) 36-54.

[45]French, S. - Emerich, M.: The LOHAS Consumer Identified. In: LOHAS Journal. 2002. 3 (1)

[46]Nielsen - Natural Marketing Institute (NMI): Green Consumers Spend More in Warehouse Clubs, and Buy More Produce, Pasta and Cereal Than Non-green Consumers - Nielsen and NMI Report. 2008. URL: http:// www.nielsen.com/content/dam/nielsen/en us/documents/pdf/Press\%20Releases/2008/ June/Green\%20Consumers\%20Spend\%20 More\%20In\%20Warehouse\%20Clubs,\%20 And\%2oBuy\% 20More\%2oProduce,\% 20 Pasta\% 20And\% 20Cereal\% 20Than\% 20 Non-Green\%20Consumers,\%20Nielsen\%20 And\%20NMI\%20Report.pdf dátuma: 2014. március 17.)
[47]Molyneaux, M.: The Changing Face of Organic Consumers. In: Food Technology. 2007. 61 (11) 22-26.

[48]Brooks, S.: The Green Consumer. In: Restaurant Business. 2009. 108 (9) 20-22.

[49]Kastenholz, E. - Lima, J.: Co-creating Quality Rural Tourism Experiences - the Case of a Schist Village in Portugal. In: International Journal of Management Cases. 2013. 15 (4) 193-204.

[50]Todt, A. - Kastenholz, E.: Tourists as a Driving Force for Sustainable Rural Development - a Research Framework. In: Actas do IV CER, Congresso de Estudos Rurais. University of Aveiro, Aveiro, 4-6 February 2010. 633-645.

[51] Vavra, B.: NATURAL Economics. In: Progressive Grocer. 2002. 81 (12) 62.

[52] Magnusson, M. K. - Arvola, A. - Koivisto Hursti, U. K. - Åberg, L. - Sjödén, P.O.: Choice of Organic Foods is Related to Perceived Consequences for Human Health and to Environmentally Friendly Behaviour. In: Appetite. 2003. 40 (2) 109-117.

[53]Wandel, M. - Bugge, A.: Environmental Concern in Consumer Evaluation of Food Quality. In: Food Quality and Preference. 1997. 8 (1) 19-26. 


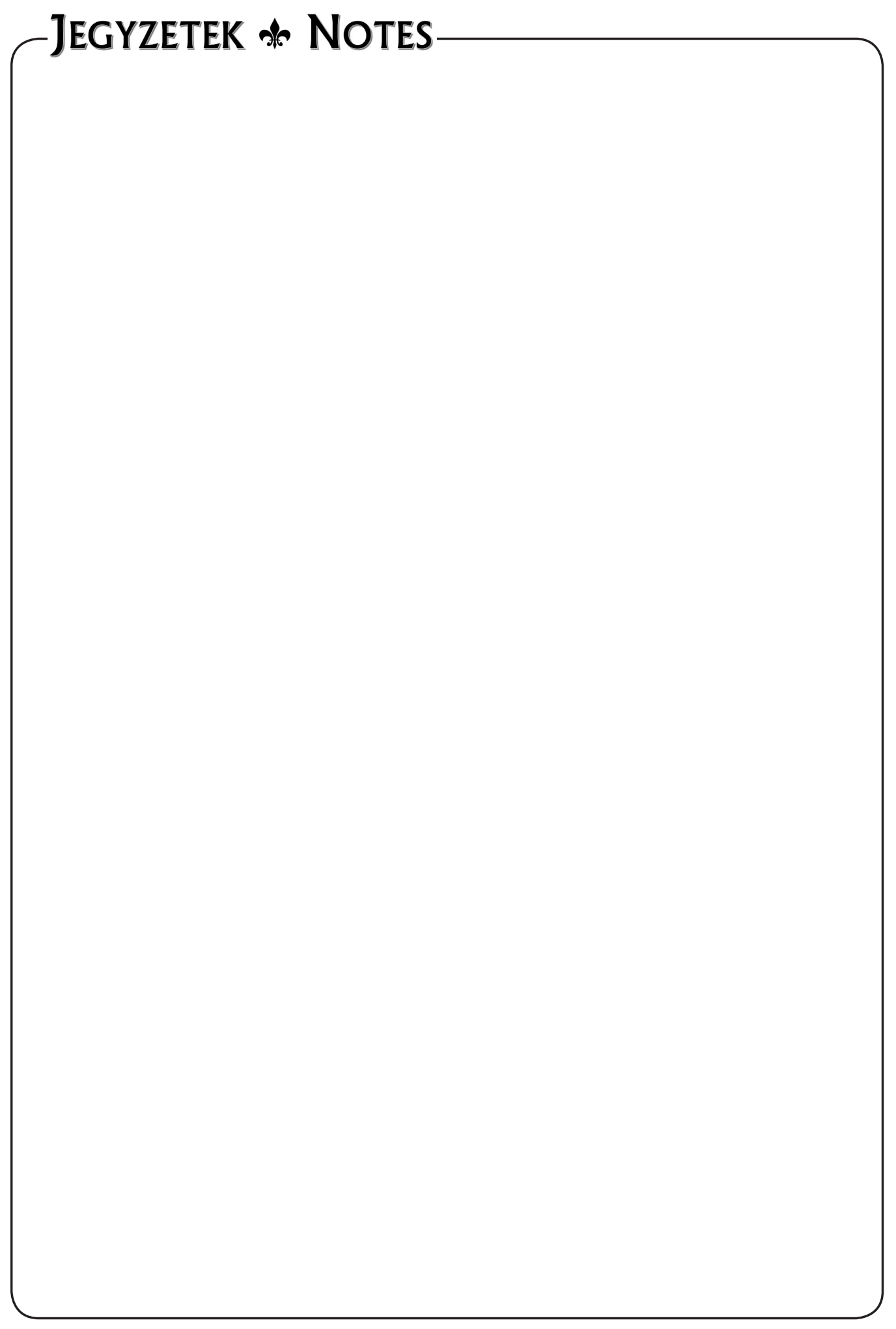

